\title{
Research-Oriented Collaborative Inquiry Learning (REORCILEA) Model: Improvement of Students' Analytical Thinking Ability in High School Chemistry Learning
}

\author{
Hendrawan Banu Huda ${ }^{1, *}$ Eli Rohaeti ${ }^{2}$ \\ ${ }^{I}$ Master of Chemistry Education Program, Faculty of Mathematics and Natural Sciences, Universitas Negeri \\ Yogyakarta, Indonesia \\ ${ }^{2}$ Department of Chemistry, Faculty of Mathematics and Natural Sciences, Universitas Negeri Yogyakarta, \\ Indonesia \\ *Corresponding author. Email: hendrawanbanu.2018@student.uny.ac.id
}

\begin{abstract}
This study aimed to determine the effect of applying the Research-Oriented Collaborative Inquiry Learning (REORCILEA) learning model on students' analytical thinking skills on the concept of acid-base. Participants in this study were 64 high school students divided into two groups: the control class and the experimental class. The sampling technique used was the random sampling technique. Data on students' analytical thinking skills were collected using post-test questions in descriptions containing indicators of analytical thinking skills with validity and reliability of the items are in good category. Analytical thinking ability data were analyzed using independent t-test. The results showed a significant effect of implementing the REORCILEA learning model on students' analytical thinking skills. Students' analytical thinking ability profile is known to have the highest percentage with a very high category, and the connecting aspect has the lowest percentage with the high category.
\end{abstract}

Keywords: REORCILEA Model, Anlytical thinking ability, Acid base

\section{INTRODUCTION}

Learning is part of education to develop individuals through interactions between students and teachers. Learning can also be formal and informal, where there are reciprocities that lead to a deeper understanding of a topic or material [1]. According to Yoon [2], many students do not have a good relationship with their teacher. As a result of this, student participation is low, and students only memorize the teacher's information. Learning does not train students to carry out higher-order thinking processes [3]. Learning chemistry, which is a branch of applied science, is an important thing in its existence in the learning process so that chemistry is easy to understand properly. Chemistry learning topics consist of knowledge that contains concepts, principles, and facts [4]. Studying chemistry allows students to understand what is happening around them, but chemistry has many abstract and difficult concepts to understand [5]. According to Gladys et al. [6], one of the difficult category chemicals is acids, bases, and salts. Analytical thinking includes the skills needed in problem-solving in chemistry learning.

Analytical thinking is a higher-order thinking skill that can train to understand information in-depth, detail, and connect between parts or components[7]. Analytical thinking ability can visualize, articulate, and solve a complex problem, making logical decisions based on the information obtained [8]. According to Anderson [7], actions included in the ability to think analytically are classified into three groups of cognitive dimensions, (1) Differentiating is the ability to distinguish relevant or important parts from irrelevant or insignificant parts of the material presented; (2) Organizing is the ability to determine how elements fit or function in a structure; and (3) Connecting is Deconstructing to determine the point of view, bias, value, or purpose that underlies the material presented. The ability to think has relatively 
limited brain capacities, so it needs to be trained with various scientific approaches [9].

The REORCILEA model is a constructive learning model that places students as learning subjects. The REORCILEA model is designed by integrating the principles of inquiry, collaborative and research-based learning to facilitate students to be more active and integrate learning with experiments [10]. Compared to learning that uses a teacher-centered approach, cooperative learning is more effective in increasing students 'conceptual understanding, attitudes of interest, and developing students' skills [11]. The application of learning in the laboratory leads to better learning and is also more permanent 6 . This process demands students to answer questions and investigate, explore research, and study [13]. Using ResearchOriented Research Inquiry Learning Models (REORCILEA), students become more active in their learning of seeing, testing, and conducting experiments [10]. Active learning allows students to engage in higher-order thinking skills processes and shared thinking processes [14]

In learning chemistry, students need high-level thinking skills such as analytically thinking ability in solving problems and a better understanding of chemical materials. The ability to think the analysis is an ability that needs to be trained so that students can master it with active learning. The REORCILEA learning model is a model that stimulates students to be active and independent in learning. Learning the active role of students is very influential in learning achievement and provides meaningful experiences to students. This model can be used as an alternative learning model that can improve higher-order thinking skills, which are indispensable in constructing new knowledge.

\section{RESEARCH METHODS}

The type of this research is a quasi-experiment with a post-test only with a nonequivalent control group design. The sample used in this study were students of class XI IPA at SMA Negeri 4 Rejang Lebong. The sampling technique used in this study was random sampling, which is a random sampling technique for a group to determine the control class and the experimental class, each consisting of 32 students.

The control class is a group that uses the learning method used in the school, namely teacher-centered learning, and the experimental class using the REORCILEA learning model was developed by Irwanto [10], which has five learning activity stage. (1) the initiating phase of students being given problems contextual and motivated to solve problems based on various information that students can get from books, articles, or other relevant sources, which are then used to design experiments. (2) Hypothesizing phase in this phase, students ask several questions and draw hypotheses from these questions based on information from various relevant literature. (3) In the experimenting phase, the students conducted experiments to test the hypotheses that had been made based on the experimental design that had been made previously. (4) In the writing phase, the students collect and organize the experimental data obtained and present it in the form of tables or graphs and write reports on the results of the experiments that have been carried out. (5) In the evaluating and reflecting phase in this phase, the students communicate the experiment results and evaluate and reflect on them. The research instrument used to determine the ability to think analytically is an analytical thinking test.

Data on students' analytical thinking skills were collected using test questions in the form of an essay on acid-base consisting of 12 questions at the end of the learning process in both the experimental and control classes. Analytical thinking skills test questions used in this study were made based on indicators of analytical thinking skills, according to K. Carr and E. Sparks [9] that is differentiating, attributing, and organizaing. Before using the post-test analytical thinking ability questions, it was first analyzed using the Rasch model to determine validity and reliability. The results of the analysis show that the validity and reliability of the items are in good category.

Data were analyzed using the Independent t-test to determine the REORCILEA learning model's effect on students' analytical thinking skills, which were previously treated by Levene's test were performed and the Shapiro-Wilk test to determine the assumption of normality and homogeneity (sig.>0,05). The percentage of students' analytical thinking skills is interpreted based on the criteria in Table 1.

Table 1. Categorization of students' analytical thinking

\begin{tabular}{|c|l|}
\hline Percentage score (\%) & Criteria \\
\hline $81-100$ & Very High \\
\hline $61-80$ & High \\
\hline $41-60$ & Fair \\
\hline $21-40$ & Low \\
\hline $0-20$ & Very Low \\
\hline
\end{tabular}




\section{RESULT AND DISCUSSION}

\subsection{The Difference in Students' Analytical Thinking Skills Between Two Groups}

In this study, the ability to think analytically was known based on the post-test scores' results using questions of analytical thinking skills. The questions used contain aspects of the analytically thinking ability and descriptive questions consisting of 13 total questions.

The data on students' analytical thinking abilities obtained were then analyzed using the t-test technique. Levene's Test for Equality of Variances was used to determine homogeneity, and the Shapiro-Wilk test was used to determine normality. Levene's Test for Equality of Variances and the Shapiro-Wilk test shown in table 2 .

Table 2. The normality and homogeneity test

\begin{tabular}{|l|l|l|l|l|}
\hline \multicolumn{2}{|l|}{$\begin{array}{l}\text { Levene's Test for } \\
\text { Equality of } \\
\text { Variances }\end{array}$} & \multicolumn{3}{l|}{ Shapiro-Wilk } \\
\hline F & Sig. & Statistic & Df & Sig \\
\hline 0.360 & 0.551 & $\begin{array}{l}\text { Experiment: } \\
0.943\end{array}$ & 32 & 0.093 \\
Control: 0.945 & 32 & 0.102 \\
\hline
\end{tabular}

Table 2 show that the sig value of both is greater than 0.05 , indicating the value of students' analytical thinking skills is homogeneous and normally distributed. After finding the homogeneity and normality of the analytical thinking ability data, the independent variable $\mathrm{t}$-test was carried out to determine whether there was a statistically significant difference in the two sample groups' analytical thinking ability scores.

Table 3. Results of the Independent T-Test analysis of students' analytical thinking skills

\begin{tabular}{|l|l|l|l|}
\hline$t$ & df & Sig. & $t$ \\
\hline 3,041 & 62 & 0,003 & 3,041 \\
\hline
\end{tabular}

Table 3 shows the t-test analysis of the students' analytical thinking ability scores and the known sig. $<0.05$, which means a significant effect of applying the REORCIELA learner model on students' analytical thinking abilities. This influence is caused because learning with the REORCILEA model makes students more active in learning and makes students the center of learning activities to provide a more meaningful learning experience and improve students' ability to differentiate, organize and connect the information needed problem-solving activities. The same thing in Tatsuoka et al. [15] that states students' operational activities seeking and finding answers to a student's problem require critical and analytical thinking.

Activities to find answers to a problem provide opportunities for students to discuss and collaborate. Previous research that has been carried out regarding the principle of integrated learning, the REORCILEA model has shown positive effects such as inquirybased learning by Nuangchalerm \& Thammasena [16], collaborative learning conducted by Jong [17], and research-oriented learning conducted by Hue et al. [18].

\subsection{Analytical Thinking Skills Profiles in The REORCILEA Study Group}

The profile of the analytical thinking ability of students who take part in the learning process using the REORCILEA learning model is known based on the percentage of the post-test value of the analytical thinking ability on acid-base material in the form of essays and contains indicators of analytical thinking skills such as distinguishing, connecting, and organizing.

Table 4 shows the percentage of each category of students' analytical thinking abilities in the class that applies the REORCILEA learning model the post-test score analysis results. The results of the analysis show that the differentiating indicator has the highest percentage, namely $91.63 \%$ with the very high category, and the organizing indicator has the lowest percentage, namely $62.00 \%$ with the high category and the average percentage of students' analytical thinking ability is $72.56 \%$ with the high category. Previous research conducted by Irwanto et al. [19] shows that the connecting aspect has the lowest percentage compared to other aspects. The connecting aspect is the student's ability to determine the point of view of the information obtained [20]

Table 4. Percentage and category of Analytical thinking ability aspect

\begin{tabular}{|l|l|l|}
\hline $\begin{array}{l}\text { Aspects of } \\
\text { Analytical } \\
\text { Thinking Skills }\end{array}$ & $\begin{array}{l}\text { Percentage } \\
(\%)\end{array}$ & Category \\
\hline Differentiating & 91.63 & Very High \\
\hline Organizing & 64.03 & High \\
\hline Attributing & 62.00 & High \\
\hline Average & 72,56 & High \\
\hline
\end{tabular}




\section{CONCLUSION}

This study concludes that the REORCILEA learning model can significantly improve students' analytical thinking skills. This increase in inability is due to the REORCILEA learning model. It places students at the center of learning activities and stimulates students to be independent, discuss solving problems, and provide meaningful learning experiences in constructing new knowledge. Students' analytical thinking ability profile shows that the highest percentage of analytical thinking skills is differentiating, and the lowest is connecting. Furthermore, this model can be used as an alternative model for innovation in learning.

\section{ACKNOWLEDGMENTS}

Special thanks to the Ministry of Education and Culture, Indonesia by supporting fund via Hiba Pasca year 2020 .

\section{REFERENCES}

[1] A. Pritchard, New Ways of Learning: Learning theories and learning styles in the classroom Second Edition, Routledge, 2007.

[2] J-S. Yoon, Teacher Characteristics as Predictors of Effectiveness, Social Behavior and Personality 30(5) (2002) 485-494. DOI : https://doi.org/10.4314/sophia.v9i2.38805

[3] E. Ad'Hiya, E.W. Laksono, Students' analytical thinking skills and chemical literacy concerning chemical equilibrium, in: AIP Conference Proceedings, vol. 2021, AIP Publishing, College Park, Maryland, 2018, pp. 1-5. DOI : https://doi.org/10.1063/1.5062824

[4] S. Özgelen, Students' Science Process Skills Within A Cognitive Domain Framework, Eurasia Journal of Mathematics Science and Technology Education 8(4) (2012) 283-292. DOI : https://doi.org/10.12973/eurasia.2012.846a

[5] G. Sirhan, Learning Difficulties in Chemistry: An Overview', Journal of Turkish Science 4(2) (2007) 2-20.

[6] J-G. Uzezi, D. Ezekiel, A.-K. Musa Auwal, Assessment of Conceptual Difficulties in Chemistry Syllabus of The Nigerian Science Curriculum as Perceived by High School College Students, American Journal of Educational
Research 5(7) (2017) 710-716. DOI : https://doi.org/10.12691/education-5-7-3

[7] L.W. Anderson, B.S. Bloom, A Taxonomy for Learning, Teaching, and Assessing: A Revision of Bloom's Taxonomy of Educational Objectives, Longman, 2001.

[8] R-J. Sternberg, S-B. Kaufman, Cambridge handbook of Intelligence, Cambridge University Press, 2011.

[9] K. Carr, E. Sparks, Thinking Skills for Strategic Capability: A Psychological Perspective. Cranfield University, 2011.

[10] E. Rohaeti, A-K. Prodjosantoso, Irwanto, Research-Oriented Collabirative Inquiry Learning Model: Improving Students' Scientific Attitudes in General Chemistry, Journal of Baltic Science Education 19(1) (2020) 108-120. DOI : https://doi.org/10.33225/jbse/20.19.108

[11] L. Tarhan and B-S. Sesen, Jigsaw Cooperative Learning: Acid-base Theories, Chemistry Education Research and Practice 13(3) (2012) 307-313. DOI https://doi.org/10.1039/c2rp90004a

[12] C. Tüysüz, The Effect of The Virtual Laboratory on Students' Achievement and Attitude in Chemistry, International Online Journal of Educational Sciences 2(1) (2010) 37-53.

[13] C-C. Kuhlthau, L-K. Maniotes, A-K. Caspari, Guided Inquiry: Learning in The 21st Century, Libraries Unlimited, 2007.

[14] B-A. Sesen, L. Tarhan, 'Active-Learning Versus Teacher-Centered Instruction for Learning Acids and Bases, Research in Science and Technological Education 29(2) (2011) 205-226. DOI

https://doi.org/10.1080/02635143.2011.581 $\underline{630}$

[15] T. Tatsuoka, K. Shigedomi, N. Koga, Using A Laboratory Inquiry with High School Students to Determine The Reaction Stoichiometry of Neutralization by A Thermochemical Approach, Journal of Chemical Education 92(9) (2015) 1526-1530.

DOI: https://doi.org/10.1021/ed500947t

[16] P. Nuangchalerm B. Thammasena, Cognitive Development, Analytical Thinking, and Learning Satisfaction of Cognitive Development, Analytical Thinking and Learning Satisfaction of 
Second Grade Students Learned through InquiryBased Learning, Asian Social Science 5(10) (2009) 82-87. DOI: https://doi.org/10.5539/ass.v5n10p82

[17] J-P. Jong, The Effect of a Blended Collaborative Learning Environment in a Small Private Online Course (SPOC): A Comparison with A Lecture Course, Journal of Baltic Science Education 15(2) (2016) 194-203.

[18] I. Huet, N-J. Mourtos, N. Costa, O. Pacheco, and J. Tavares, Models for Research-Based Teaching in Engineering Courses: A Case-Study at The University of Aveiro (PT) and San José State University (USA), International Journal Engineering Education 3(7) (2007) 1-5.

[19] Irwanto, E. Rohaeti, E. Widjajanti, Suyanta, Students' science process skill and analytical thinking ability in chemistry learning, in: AIP Conference Proceeding, vol. 1868, AIP Publishing, College Park, Maryland, 2017, pp. 14, DOI : https://doi.org/10.1063/1.4995100

[20] R.E. Mayer, Rote Versus Meaningful Learning, Theory Into Practice 41(4) (2017) 1-7. DOI : https://doi.org/10.1207/s15430421 tip4104 